\title{
Team adherence to rapid prenatal testing and administration of benzathine penicillin in primary healthcare*
}

\author{
Adesão das equipes aos testes rápidos no pré-natal e administração da penicilina benzatina na \\ atenção primária \\ Adopción de los equipos a las pruebas prenatales rápidas y la administración de penicilina \\ benzatínica en atención primaria
}

How to cite this article:

Araújo TCV, Souza MB. Team adherence to rapid prenatal testing and administration of benzathine penicillin in primary healthcare. Rev Esc Enferm USP. 2020;54:e03645. doi: https://doi.org/10.1590/S1980-220X2019006203645

\section{Túlio César Vieira de Araújo ${ }^{1}$}

Marize Barros de Souza ${ }^{1}$

* Extracted from the dissertation: "Adesão dos serviços de atenção básica ao teste rápido para as infecções sexualmente transmissíveis", Universidade Federal do Rio Grande do Norte, 2019.

${ }^{1}$ Universidade Federal do Rio Grande do Norte, Escola de Saúde, Natal, RN, Brazil.

\begin{abstract}
Objective: To identify the factors related to the work process regarding the adherence of Primary Healthcare teams to the rapid test for HIV, syphilis, hepatitis B and C during prenatal care and administration of benzathine penicillin in primary healthcare. Method: A descriptive, exploratory and quantitative study conducted between the months of July and November 2018, with professionals from the Family Health Strategy teams of the Seridó Norte-Rio-Grandense region in Rio Grande do Norte State, Brazil. Results: There were 18 municipalities, 94 Basic Health Units and 100 Family Health Strategy teams which participated in the study. The nurse was the main person involved in the testing service, and $93 \%$ of the interviewed teams offered the test in the service routine. Of these teams, $97.8 \%$ underwent prenatal testing, $51.6 \%$ offered the test to the pregnant woman at the beginning of the third trimester, and $57 \%$ offered the rapid test to sexual partners. Benzantine penicillin was available in $87.1 \%$ of the teams; however, $49.5 \%$ did not administer the medication in primary healthcare. Conclusion: The testing process proved to be fragile because even if the test was available in prenatal care, the other activities linked to the work process did not occur properly.
\end{abstract}

\section{DESCRIPTORS}

Prenatal Care; Point-of-Care Testing; Primary Care Nursing; HIV; Syphilis; Hepatitis, Viral, Human. 


\section{INTRODUCTION}

"Improving the quality of prenatal care and expanding its access within the scope of the Family Health Strategy (FHS) are relevant initiatives, as their adequate structuring and provision have positive results in reducing maternal and child morbidity and mortality"(1). Educational actions carried out during follow-up are shown as opportune spaces for reflection, sharing knowledge, questioning reality and to deconstruct ideas which are crystallized in society. Communicative action and dialogicity equip women regarding protective measures against Sexually Transmitted Infections (STIs), as well as to assume a proactive role in their sexuality and reproduction, encouraging them to make conscious and safe choices ${ }^{(2)}$.

However, the increase in cases of HIV, syphilis, hepatitis $\mathrm{B}$ and $\mathrm{C}$ during pregnancy raises great concern in individual and collective terms. Up to $8 \%$ of pregnant women are infected with the hepatitis $\mathrm{C}$ virus worldwide, whereas the hepatitis B virus stands out for its wide geographical distribution and great potential to cause chronic diseases such as cirrhosis and hepatocellular carcinoma ${ }^{(3-4)}$. Due to their prevalence rates, chronicity, potential for transmissibility and complications, viral hepatitis $\mathrm{B}$ and $\mathrm{C}$ are of great relevance in the field of public health in Brazil ${ }^{(5)}$.

In global terms, "it has been found that the experience of pregnancy in the presence of HIV can be especially difficult for women due to the numerous biopsychosocial implications it entails, such as the discovery and adaptation to the seropositivity condition, the need to perform antiretroviral treatment and the emergence of additional concerns about vertical transmission, and therefore about the baby's health"(6).

The Northeast region of Brazil occupies the second position in the country among syphilis notifications, carried out from 2005 to June 2018, regarding pregnant women, with $20.5 \%$ of cases. "The number of notifications from 2016 to 2017 increased in all regions, with an emphasis on a 38\% increase in the Northeast Region. Syphilis during gestation leads to more than 300,000 fetal and neonatal deaths per year worldwide and increases the risk of premature death in another 215,000 children. The provision of the Rapid Test (RT) for syphilis is currently growing, but its use and coverage in Primary Healthcare (PHC) are still unsatisfactory"(7).

One of the recommended actions in prenatal care refers to the prevention, diagnosis and treatment of STIs/HIV/ AIDS, syphilis and viral hepatitis. Timely diagnosis is essential to reduce vertical transmission. In view of this, and in order to qualify maternal and child care, PHC teams are instructed to perform RTs for the diagnosis of HIV, syphilis and viral hepatitis, preferably in the first and third trimesters of pregnancy. The RTs are practical and easy to perform, with the result being read in a maximum of 30 minutes. They can be performed with whole blood samples collected by digital or venipuncture, with the advantage of being performed in a consultation, which allows immediate treatment ${ }^{(5)}$.

However, as it is only a recently inserted mechanism in Basic Health Units (UBS - Unidades Básicas de Saúde) through Ordinance No. 77 of 2012, it appears that there are gaps in the knowledge on the theme in the reality of the Seridó Region.
In view of the importance of testing in prenatal care, the incidence of hepatitis $\mathrm{C}$ in pregnant women, the syphilis epidemic and the impact of these STIs on maternal and child health, it is important to understand how the PHC teams deal with this insertion. Therefore, this study aimed to identify the factors related to the work process regarding the adherence of primary healthcare teams to the rapid test for HIV, syphilis, hepatitis $\mathrm{B}$ and $\mathrm{C}$ during prenatal care and the administration of benzathine penicillin in primary healthcare of the Seridó Region in Rio Grande do Norte state, Brazil.

\section{METHOD}

\section{Study DESIGN}

A descriptive, exploratory and quantitative study.

\section{SCENARIO}

The research was carried out with primary healthcare teams from the Seridó Region of Rio Grande do Norte $(\mathrm{RN})$. This scenario was chosen because of the teams' low record of adherence to the RT according to the results of the National Program for Improving Access and Quality in Primary Care (in Portuguese $P M A Q-A B$ ), and because the region is the researcher's field of activity.

The historically constructed delimitation of Seridó was used, which considers that the region is formed by the 23 municipalities which directly or indirectly arose from the Municipality of Caicó( ${ }^{(8)}$. Thus, 18 municipalities, 94 UBS and 100 FHS teams participated in the study. Rio Grande do Norte State is divided into eight health regions, and all the municipalities in this study belong to the same region. The study population was composed of all professionals with higher education on the team.

\section{SeleCtion CRITERIA}

The following inclusion criteria were used for health units: to be in operation during the data collection period and to be a member of the FHS, with operation for more than six months. In relation to the professional: having a university degree and being professionally employed by the UBS.

Next, one professional from each team was invited to participate by intentional sampling. One chose the one who was directly involved in the testing process; when the team did not perform the RT, a professional who had broad knowledge of the information of their team's work process was interviewed. The interviews took place in the UBS, in a reserved place.

\section{Data collection}

Data collection was carried out from July to November 2018, and took place using a semi-structured interview instrument divided into two domains, namely: characterization of the health unit and the managing professional, and rapid test in the health team. The instrument was developed based on the questions of the external evaluation of the $3^{\text {rd }}$ cycle of the PMAQ-AB and the main points pertinent to the subject identified during a literature review. 
The data were used in their entirety for a larger study linked to a Master's dissertation. A pilot test was carried out with three FHS teams from a municipality bordering the region defined in this study. The following variables were selected for the purposes of this research: training/education of the interviewed professional, city and zone of the $U B S$, RT provision by the team, professionals involved in testing, testing during prenatal care, testing on the pregnant woman's sexual partners, availability and administration of benzathine penicillin, and treatment of the partner.

\section{DATA ANALYSIS AND PROCESSING}

The data were tabulated with Microsoft Excel 2010, with the variables being grouped in the columns and the interviews in the rows for better visualization of the data. Then, the information was processed with the Statistical Package for Social Sciences (SPSS), version 20.0. The application performed statistical analysis and data visualization in the form of graphs, tables and charts.

\section{ETHICAL ASPECTS}

The research was approved by the Research Ethics Committee of the Universidade Federal do Rio Grande do Norte, Central Campus, with Opinion no. 2.529.502 of 2018 , in compliance with Resolution 466/12 of the National Health Council.

\section{RESULTS}

From the 23 municipalities in the initial sample, 18 (78.26\%) agreed to the researcher's visit to the UBS. The 18 participating cities totaled 100 UBS and 110 FHS teams; thus, 94 units (94\%) and 100 teams (90.9\%) participated in the survey, with 28 rural (28\%) and 72 urban (72\%) teams. The 18 municipalities had units represented in the study.

After the six initial interviews, it was evidenced that the nurse would be the appropriate professional to be interviewed in all units, since half of these six initial interviews were answered by other professionals and presented numerous unanswered variables, thus preventing their use. Therefore, it was decided to return to these places and repeat the interviews with the nurses. The results and discussion were grouped into two categories in order to provide a better understanding: provision of the rapid test and administration of benzathine penicillin in primary care.

\section{RAPID TEST PROVISION}

A total of seven teams (7\%) did not provide the RT for STIs in the service, with three rural and four urban teams. The reasons were: absence of the test (three teams); inadequate UBS structure (two teams); lack of training (one team); change of physical structure (one team). Figure 1 provides information regarding the testing process and the professionals involved.

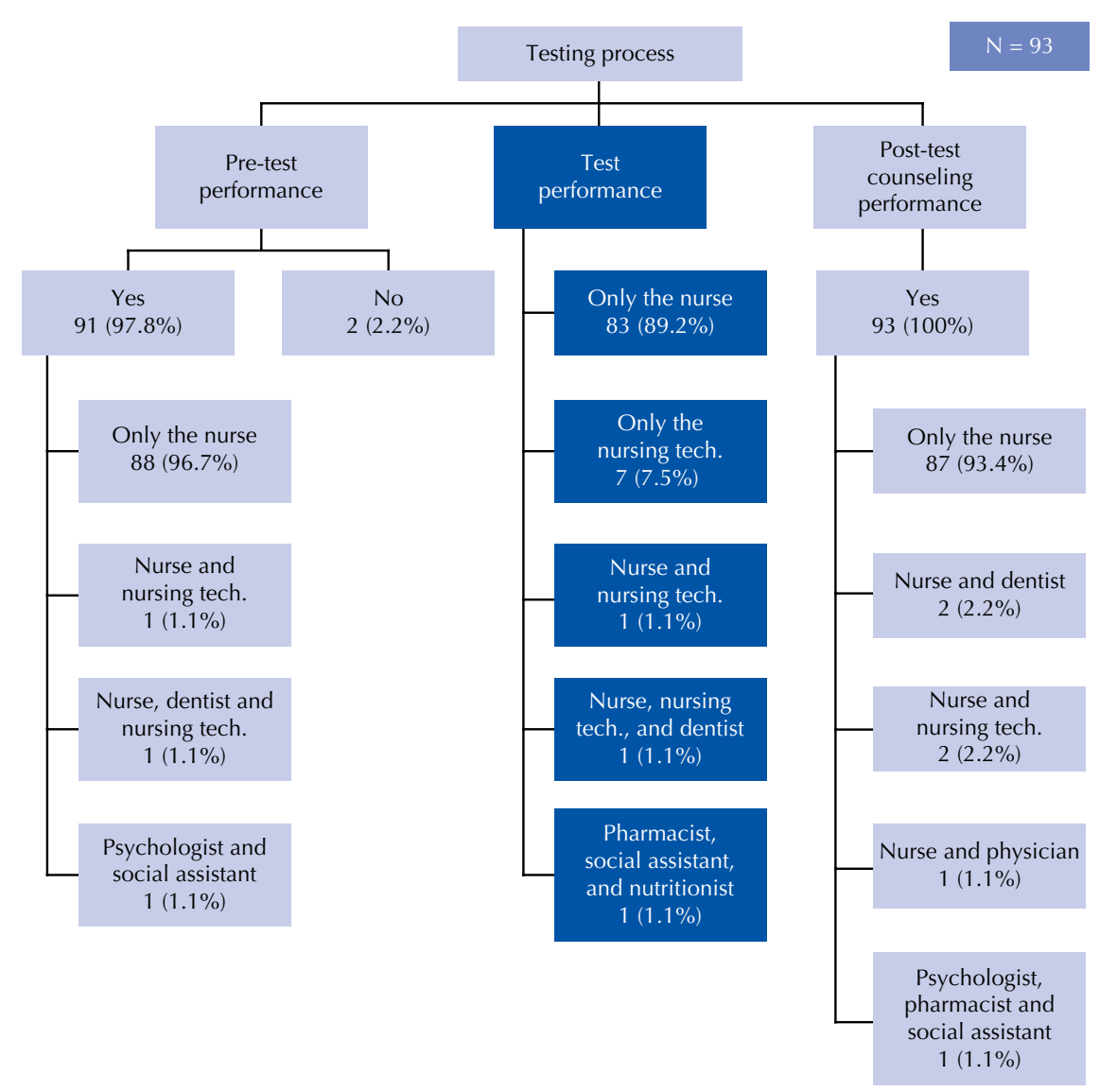

Figure 1 - Characteristics of the testing process and professionals involved in the Basic Health Units - Seridó Norte-Rio-Grandense, Brazil, 2018. 


\section{ADMINISTRATION OF BENZATHINE PENICILLIN IN}

\section{PRIMARY HEALTHCARE}

Benzathine penicillin was available to 81 teams (87.1\%), and 47 (50.5\%) of them administered the medication in the unit. When asked about treating the partner of a pregnant woman with a positive result for syphilis, 11 professionals (11.8\%) started treating these partners immediately, even without the test result. Figure 2 shows information regarding the RT during prenatal care.

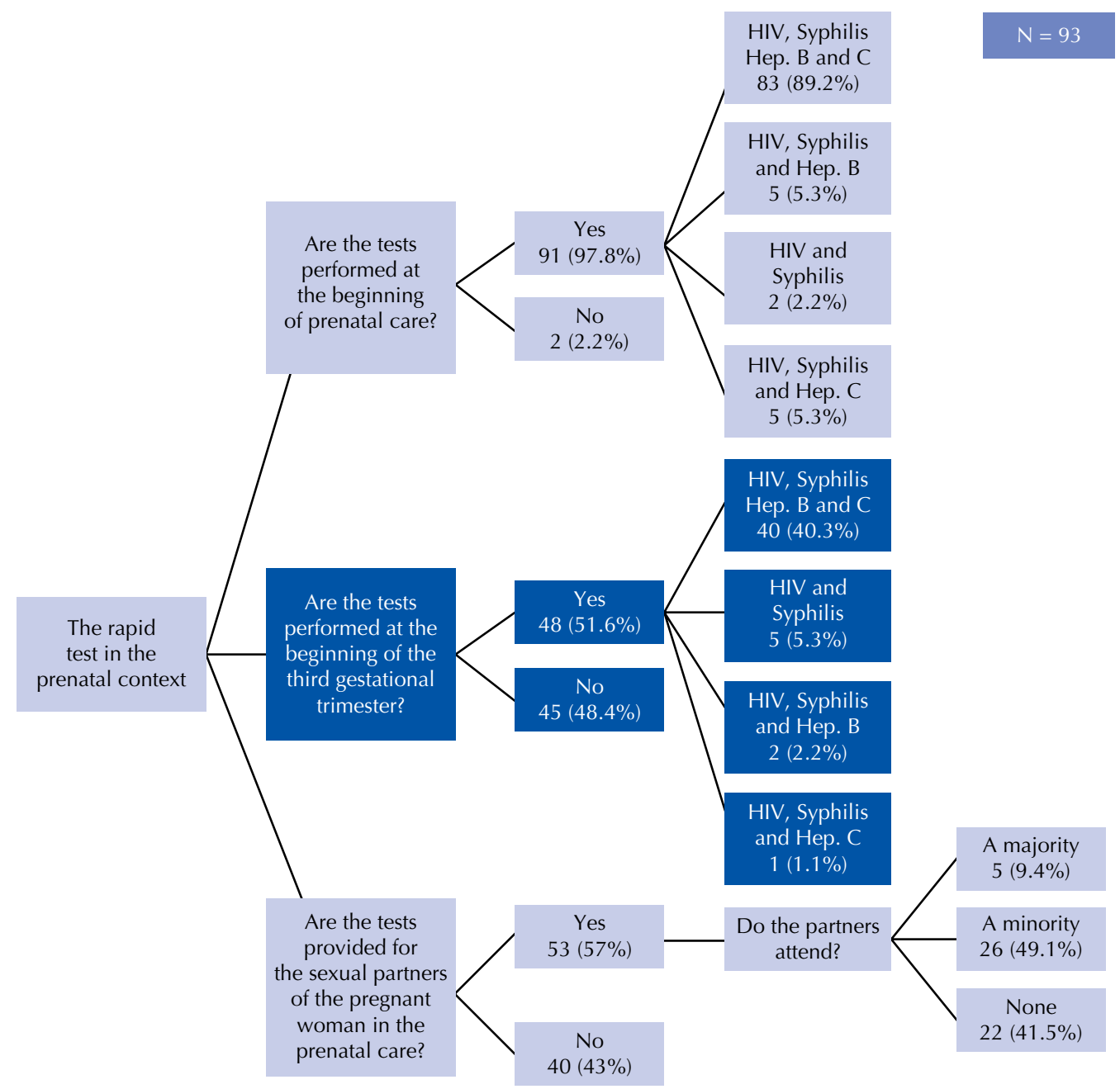

Figure 2 - Rapid test for sexually transmitted infections in prenatal care at Basic Health Units - Seridó Norte-Rio-Grandense, Brazil, 2018.

\section{DISCUSSION}

The biggest absence was on the part of the municipalities, as five $(21.7 \%)$ did not participate because the municipal health secretary did not accept or did not deliver the letter of consent. Since the non-participating municipalities have a limited number of UBS and FHS teams, the absence of the five municipalities did not impact the overall study quantity. The survey was well-accepted by the units and teams with a mean above $90 \%$, which were characterized as predominantly urban.

Of the interviewed teams, $93 \%$ provided rapid tests, which is a significant number since the process of implementing RT in PHC in Brazil has been gradually taking place $^{(9-10)}$. Findings from the external evaluation of the $1^{\text {st }}$ cycle of the PMAQ-AB in 2011 found that $96.6 \%$ and $86 \%$ of the teams stated that they never had the syphilis and HIV RTs, respectively ${ }^{(9)}$. In the $2^{\text {nd }}$ cycle of the PMAQ-AB in 2013 , syphilis tests were not available for $71 \%$ of the teams, and $70 \%$ did not have an HIV test ${ }^{(10)}$. Thus, a slow process and a series of limitations and peculiarities hindering its effectiveness is noted. In addition, the diversity of contexts in which the UBS are present implies that the process of inserting the test into the routines of the services does not uniformly occur in the country.

Professionals continue to face numerous barriers when inserting routine $\mathrm{HIV}$ tests in $\mathrm{PHC}$ settings ${ }^{(11)}$. A study with 24 UBS pointed out that the difficulties found to perform the RT were: low adherence, inadequate physical structure and tests with expired validity ${ }^{(12)}$. Research 
in southern Brazil showed that none of the trained FHS teams had implemented testing at the service, even after training and for a period of about five months. The reasons were: inadequate infrastructure; insufficient human resources; insecurity in following-up the patients with reactive $\mathrm{RT}^{(13)}$.

The findings of this study corroborate some difficulties found, such as the inadequate UBS structure. Inserting a policy in health services goes through individual factors, such as the motivation of each one, up to managerial issues such as a favorable physical structure and adequate staffing. "Regarding the decentralization of HIV-AIDS care to primary healthcare, it appears that the process involves a subjective mobilization of the worker and its effectiveness is more likely to occur under the perspective of co-responsibility, instead of transferring responsibility"(14).

Prenatal testing is a viable and acceptable intervention, with a high probability of being adopted by professionals as a routine service and being incorporated as a daily practice $^{(15)}$. Only two of the 93 teams that performed the tests did not perform it within the prenatal component, which can be considered a good result when compared to other national realities.

Confronting the good acceptance of RT in prenatal care and proving that PHC had difficulties in implementing the RTs for syphilis and HIV in the prenatal routine ${ }^{(12)}$, a study with 376 pregnant women in the period from 2015 to 2017 in Amazonas pointed out that, despite the great adherence to prenatal care (83.5\%), 255 (67.8\%) only received the diagnosis of syphilis upon admission for delivery ${ }^{(16)}$.

In São Paulo, a survey of 328 managers of the UBS in the city found that $32.9 \%$ did not have HIV testing for prenatal care, and $38.1 \%$ did not offer syphilis testing to pregnant women in the first and third trimesters of pregnancy ${ }^{(17)}$. These data suggest a decentralization process of $\mathrm{RT}$ in primary healthcare in a different way in different locations, and with the influence of several factors; among them, the context in which it is inserted.

The results showed that approximately half of the teams did not offer HIV and syphilis tests to pregnant women at the beginning of the third trimester of pregnancy, going against what the Ministry of Health recommends ${ }^{(5)}$. The integration of HIV screening in primary healthcare as part of prenatal care is viable, beneficial, increases the acceptance of HIV testing and facilitates wide geographic coverage, providing the opportunity to access a range of care, support, treatment, and eventually prevent infection transmission to the next generation ${ }^{(18)}$.

More than half of the teams provided tests for the pregnant women's sexual partners; however, their adherence was still insufficient. Corroborating this information, a study in Rio de Janeiro found that the majority of nurses (86\%) recruited the sexual partners of the pregnant women to perform the syphilis test, but when asked about the difficulties, most of them (76\%) said it was difficult for the partner to adhere to the treatment ${ }^{(19)}$. This difficulty was also observed by nurses from Ceará, who expressed identifying their partners as an obstacle in monitoring people with syphilis, as in some cases there is a multiplicity of partners, and in others the woman refuses to talk about her partners ${ }^{(20)}$.

Tracking STIs does not identify just one person, it will always be connected to a transmission network. When the disease is not identified and treated, it is perpetuated in the community and exposes the individual to reinfection if the use of condoms is not established. One third of the sexual partners of people with recent syphilis will develop syphilis within 30 days of exposure. Therefore, in addition to clinical evaluation and laboratory follow-up, if there was exposure to the person with syphilis (up to 90 days), presumptive treatment is recommended for their sexual partners, regardless of the clinical stage or signs and symptoms, with a single dosage of 2.4 million units of benzathine benzylpenicillin ${ }^{(5)}$.

A survey in the Southeast of the country identified that $64.9 \%$ of UBS indicated treatment with Benzathine Penicillin for partners of a pregnant woman diagnosed with syphilis, without request or test result ${ }^{(17)}$. Contrasting with what is recommended by the Ministry of Health, the result of this study showed that only a small portion of the interviewees (11.8\%) would start presumptive treatment of the pregnant partner with a positive result for syphilis without the exams confirming it, making it difficult to interrupt the transmission chain, increasing the possibility of reinfection of pregnant women and vertical transmission.

As worrisome as pregnant partner's non-immediate treatment with syphilis was the fact that, even though most units having benzathine penicillin available (87.1\%), about half of the professionals did not administer the medication at the UBS. Benzathine benzylpenicillin is currently the drug of choice for treating syphilis, being the only drug with documented efficacy during pregnancy ${ }^{(8)}$. A metaanalysis carried out in 43 countries confirmed the reduction of fetal death and neonatal death in pregnant women with syphilis who underwent treatment with benzathine penincillin. Therapy reduced the incidence of fetal death and neonatal death by $80 \%$ and congenital syphilis by $97 \% \%^{(19,21)}$.

The great challenge to be faced "for administering benzathine penicillin in UBS is the professionals' fear of the occurrence of adverse events, especially an anaphylactic reaction, without the resources to reverse these conditions. Even though there is research indicating that the occurrence of allergic reactions is estimated at $2 \%$ per treatment and that anaphylactic reactions occur in only $0.01 \%$ to $0.05 \%$ of patients treated with penicillin, with approximately two deaths per 100,000 treatments"(22), there is still high resistance.

Research carried out with 376 cases of congenital syphilis concluded that "although there is a diagnosis and effective treatment for gestational and congenital syphilis, they persist as a serious public health problem since prenatal care is still not of high enough quality and it is not enough to guarantee syphilis control"(16). Another factor that possibly contributes to the professionals' resistance is a wide history of decisions about the administration of penicillin in PHC in Brazil, as shown in Chart 1. 
Chart 1 - Normative decisions regarding the administration of benzathine penicillin in Brazilian Primary Healthcare - Brazil, 2006 to 2017.

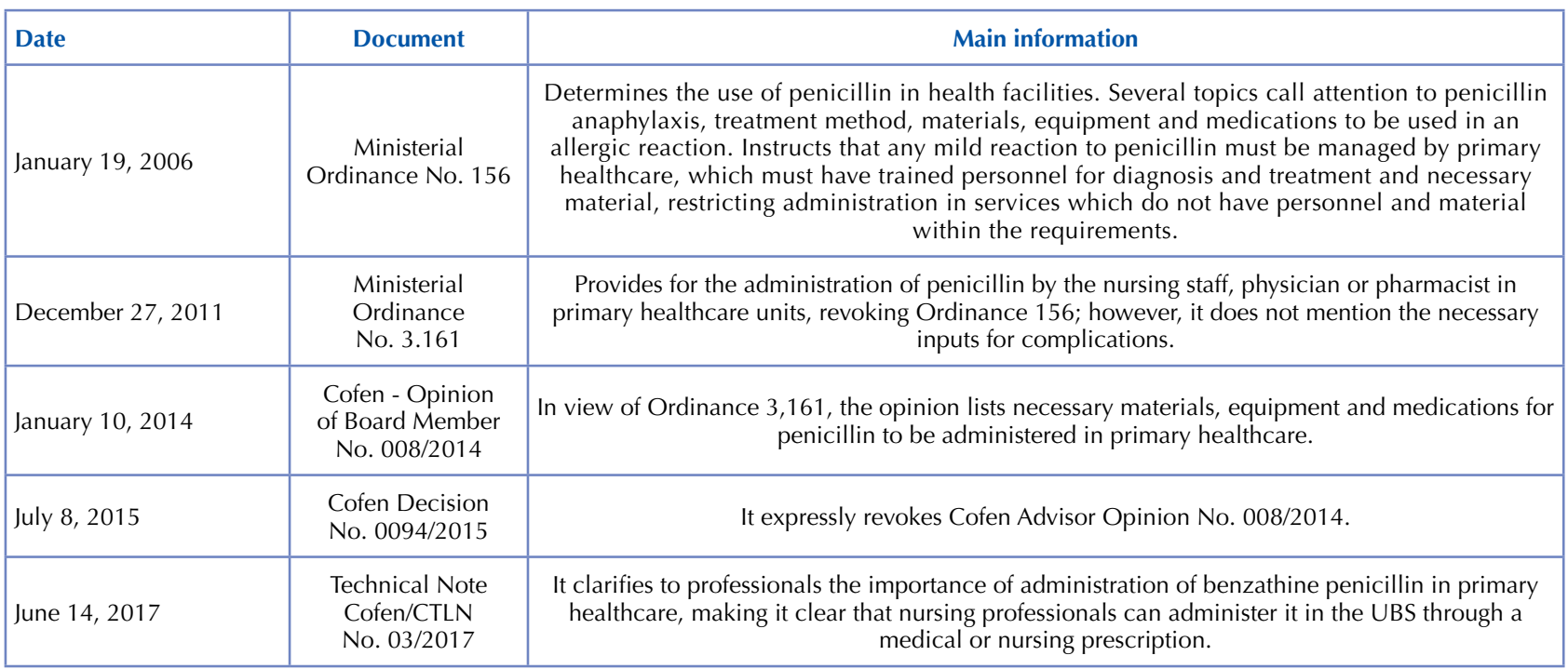

Source: Ministerial Ordinance No. 156, Ministerial Ordinance No. 3.161, Cofen Advisory Opinion No. 008/2014, Cofen Decision No. 0094/2015, Technical Note Cofen/CTLN No. 03/2017

The amount of information published over the years reinforces the resistance of professionals who sometimes end up basing their decisions on revoked regulations when they do not update themselves. The workload of the nursing team, especially nurses working in PHC, also possibly has an influence on the resistance of these professionals. The results show that the nurse appears as the only professional responsible for all stages in the testing process on about $90 \%$ of the teams.

Professionals who acted as matrix teams in order to carry out counseling and rapid testing in PHC found that the categories which most participated in the matrix support were nurses and in some cases, physicians, thus emphasizing the importance of having more than one trained professional on the team ${ }^{(23)}$. Counseling issues are known to represent a major challenge in accepting the test. Although it is necessary to speed up the diagnosis, it is also important to provide the relevant conditions and guidelines so that the service is comprehensive. Pre- and post-test counseling is extremely important for the woman to leave the office with her doubts clarified ${ }^{(24)}$.

Even though counseling was essential in the testing, research in the gynecology services of the $\mathrm{PHC}$ with women who underwent HIV testing pointed out that the awareness and counseling strategy was not carried out with any of the users $^{(25)}$. A study with HIV-positive individuals found that less than a third received guidance in the pre-test, which was summarized in the explanation about the motivation of the exam ${ }^{(26)}$.

Among 16 pregnant women interviewed in Rio de Janeiro, $93.75 \%$ stated that no guidance on STIs was provided during prenatal care, noting the large gap existing in prenatal care regarding the approach to this theme ${ }^{(2)}$. With the results of this study, it appears that the accumulation of all testing stages in the nurse overloads them, which can in some way contribute to an inadequate work process.

The study showed the role of nurses in the testing process in all its phases. It is a positive point when it is understood that $\mathrm{PHC}$ is contributing to the autonomy of nurses through incorporating new skills and technologies. In this context, the professional needs to be able to identify the social health needs of the population under their responsibility, in addition to intervening in the health/disease process of individuals, family and community ${ }^{(27)}$.

However, it is emphasized that it is important that the other categories get involved in the theme and also feel responsible for the RT. Health services will be moving towards comprehensiveness in healthcare and a more shared work process when testing becomes the responsibility of the team and not of a single profession. The weaknesses identified serve as a contribution for opening a premise for reflections on the subject in the different realities of health services.

This study has the following limitations: the lack of willingness of some managers to carry out the research; the fact that it is a loco-regional study, which may not represent the national reality. However, as it is a topic of epidemiological relevance and current in the world debate, its potential to contribute to the theme is highlighted.

\section{CONCLUSION}

It is noteworthy that despite this being a loco-regional study, there was considerable scope. In addition, the research is pioneering in having a region never studied in previously published publications on the subject. Finally, it is evident that the study launches suggestions for the future of the studied services in daily practice, in addition to the research contributing to others which may occur in different scenarios. 
Primary Healthcare in relation to the rapid test for STIs within the prenatal component is still deficient, because even though the teams have good adherence to the test, the factors associated with it such as carrying out the test in the recommended period, testing the sexual partners of the pregnant woman, administration of benzathine penicillin and involvement of the team still did not occur satisfactorily. It is not enough to provide the population with access to the service; it is necessary for this service to happen with the minimum necessary quality conditions for both users and professionals.

Promoting the decentralization of rapid STI testing for PHC is an important and necessary step which still needs to be taken with the delicacy of realizing whether the path is conducive to this. Furthermore, it is essential to identify the main challenges along this path, and outline alternatives to overcome them in the best possible way.

\section{RESUMO}

Objetivo: Identificar os fatores relacionados ao processo de trabalho no que se refere à adesão das equipes de Atenção Primária ao teste rápido para $\mathrm{HIV}$, sífilis, hepatites $\mathrm{B}$ e $\mathrm{C}$ durante o acompanhamento do pré-natal e a administração da penicilina benzatina na atenção primária à saúde. Método: Estudo descritivo, exploratório, quantitativo, realizado entre os meses de julho e novembro de 2018, com profissionais das equipes da Estratégia de Saúde da Família do Seridó Norte-Rio-Grandense. Resultados: Participaram do estudo 18 municípios, 94 Unidades Básicas de Saúde e 100 equipes de Estratégia de Saúde da Família. O enfermeiro era o principal envolvido no serviço de testagem, $93 \%$ das equipes entrevistadas ofereciam o teste na rotina do serviço. Dessas equipes, $97,8 \%$ realizavam a testagem no pré-natal, $51,6 \%$ disponibilizavam o teste para a gestante no início do terceiro trimestre e $57 \%$ ofereciam o teste rápido para os(as) parceiros(as) sexuais. A penicilina benzantina estava disponível em $87,1 \%$ das equipes, todavia, 49,5\% não administravam a medicação na atenção primária. Conclusão: $O$ processo de testagem se mostrava fragilizado, pois, mesmo havendo disponibilidade do teste no pré-natal, as demais atividades interligadas ao processo de trabalho não ocorriam adequadamente.

\section{DESCRITORES}

Cuidado Pré-Natal; Testes Imediatos; Enfermagem de Atenção Primária; HIV; Sífilis; Hepatite Viral Humana.

\section{RESUMEN}

Objetivo: Identificar los factores relacionados con el proceso de trabajo relativo a la adhesión de los equipos de atención primaria a las pruebas rápidas de detección del VIH, la sífilis y la hepatitis B y C durante el seguimiento prenatal y la administración de penicilina benzatínica en la atención primaria de salud. Método: Estudio descriptivo, exploratorio y cuantitativo, realizado entre julio y noviembre de 2018, con profesionales de la Estrategia de Salud Familiar de la región Seridó en el Río Grande do Norte. Resultados: Participaran del estudio 18 municipios, 94 Unidades básicas de salud y 100 equipos de Estrategia de Salud Familiar. El enfermero fue el principal involucrado en el servicio de pruebas, el 93\% de los equipos entrevistados ofrecieron la prueba en la rutina del servicio. De estos equipos, $97,8 \%$ realizó la prueba prenatal, 51,6\% puso la prueba a disposición de la mujer embarazada al principio del tercer trimestre y el 57\% ofreció la prueba rápida para parejas sexuales. El 87,1\% de los equipos disponía de penicilina benzatina, pero el 49,5\% no la administraba en la atención primaria. Conclusión: El proceso de prueba se debilitó porque, aunque la prueba estaba disponible en el período prenatal, las demás actividades relacionadas con el proceso de trabajo no se desarrollaron adecuadamente.

\section{DESCRIPTORES}

Atención Prenatal; Pruebas en el Punto de Atención; Enfermería de Atención Primaria; VIH; Sífilis; Hepatitis Viral Humana.

\section{REFERENCES}

1. Guimarães WSG, Parente RCP, Guimarães TLF, Garnelo L. Acesso e qualidade da atenção pré-natal na Estratégia Saúde da Família: infraestrutura, cuidado e gestão. Cad Saúde Pública. 2018;34(5):e00110417. DOI: http://dx.doi.org/10.1590/0102-311X00110417

2. Mouta RJO, Oliveira CL, Medina ET, Prata JA, Correia LM, Mota CP. Fatores relacionados ao não uso de medidas preventivas das infecções sexualmente transmissíveis durante a gestação. Rev Baiana Enferm. 2018;32:e26104. DOI: http://dx.doi.org/10.18471/rbe. v32.26104

3. Spera AM, Eldin TK, Tosone G, Orlando R. Antiviral therapy for hepatites C: has anything changed for pregnant/lactating women? World J Hepatol. 2016;8(12):557-65. DOI: http://dx.doi.org/10.4254/wjh.v8.i12.557

4. Passos ADC. Aspectos epidemiológicos das hepatites virais. Medicina (Ribeiro Preto). 2003;36(1):30-6. DOI: https://doi.org/10.11606/ issn.2176-7262.v36i1p30-36

5. Brasil. Ministério da Saúde; Secretaria de Vigilância em Saúde, Departamento de DST, Aids e Hepatites Virais. Protocolo Clínico e Diretrizes Terapêuticas para Atenção Integral às Pessoas com Infecções Sexualmente Transmissíveis [Internet]. Brasília; 2018 [citado 2019 jan. 15]. Disponível em: http://www.aids.gov.br/pt-br/pub/2015/protocolo-clinico-e-diretrizes-terapeuticas-para-atencao-integral-pessoascom-infeccoes

6. Levandowski DC, Pereira MD, Dores SDS, Ritt GC, Schuck LM, Sanches IR. Experiência da gravidez em situação de seropositividade para VIH: revisão da literatura brasileira. Análise Psicol. 2014;32(3):259-77. DOI: https://doi.org/10.14417/ap.575

7. Boletim Epidemiológico de Sífilis. Brasília: Ministério da Saúde; Secretaria de Vigilância em Saúde [Internet]. 2018 [citado 2019 jan. 15];49(45). Disponível em: http://www.aids.gov.br/pt-br/pub/2018/boletim-epidemiologico-de-sifilis-2018

8. Morais IRD. Seridó Norte-Rio-Grandense: uma geografia da resistência. Caicó, RN: Ed. do Autor; 2005.

9. Mizevski VD, Brand EM, Calvo KS, Bellini FM, Machado VS, Duarte ERM, et al. Disponibilidade do teste rápido para sífilis e anti-HIV nas Unidades de Atenção Básica do Brasil, no ano de 2012. Saúde Redes [Internet]. 2017 [citado 2019 jan. 25];3(1):40-9. Disponível em: http://revista.redeunida.org.br/ojs/index.php/rede-unida/article/view/823

10. Brasil. Ministério da Saúde; Secretaria de Atenção à Saúde, Departamento de Atenção Básica. Microdados da avaliação externa [Internet]. Brasília; 2019 [citado 2019 jan. 25]. Disponível em: https://aps.saude.gov.br/ape/pmaq/ciclo3/ 
11. WhiteBL,Walsh J, Rayasam S, Pathman DE, AdimoraAA, Golin CE. What makes me screen for HIV? Perceived barriers and facilitators to conducting recommendedroutineHIV testing among Primary Carephysicians in theSoutheastern UnitedStates.JIntAssocProvidAIDSCare.2015;14(2):127-35. DOI: http://dx.doi.org/10.1177/2325957414524025

12. Lopes ACMU, Araújo MAL, Vasconcelos LDPG, Uchoa FSV, Rocha HP, Santos JR. Implementation of fast tests for syphilis and HIV in prenatal care in Fortaleza - Ceará. Rev Bras Enferm. 2016;69(1):54-58. DOI: http://dx.doi.org/10.1590/0034-7167.2016690108i

13. Nascimento DSF, Silva RC, Tártari DO, Cardoso EK. Relato da dificuldade na implementação de teste rápido para detecção de sífilis em gestantes na Atenção Básica do SUS em um município do Sul do Brasil. Rev Bras Med Fam Comun. 2018;13(40):1-8. DOl: http://dx.doi. org/10.5712/rbmfc13(40)1723

14. Zambenedetti G, Silva RAN. Descentralização da atenção em HIV-Aids para a Atenção Básica: tensões e potencialidades. Physis. 2016;26(3):785-806. DOI: http://dx.doi.org/10.1590/S0103-73312016000300005

15. Bocoum FY, Tarnagda G, Bationo F, Savadogo JR, Nacro S, Kouanda S, et al. Introducing onsite antenatal syphilis screening in Burkina faso: implementation and evaluation of a feasibility intervention tailored to a local context. BMC Health Serv Res. 2017;17(1):378. DOI: 10.1186/S12913-017-2325-x

16. Saback MC, Viana JFS, Adorno SS, Costa MCB, Gomes KAS, Belém GLS, et al. Perfil epidemiológico da sífilis gestacional e congênita na Maternidade Ana Braga - Manaus, Amazonas. Rev Eletr Acervo Saúde 2019;11(5):e299. DOI: https://doi.org/10.25248/reas.e299.2019

17. Val LF, Nichiata LYI. Comprehensiveness and programmatic vulnerability to stds/hiv/aids in primary care. Rev Esc Enferm USP. 2014;48(n. spe):145-51. DOI: https://doi.org/10.1590/S0080-623420140000600021

18. Bindoria SV, Devkar R, Gupta I, Ranebennur V, Saggurti N, Ramesh S, et al. Development and pilot testing of HIV screening program integration within public/primary health centers providing antenatal care services in Maharashtra, India. BMC Res Notes. $2014 ; 7: 177$. DOI: $10.1186 / 1756-0500-7-177$

19. Machado I, Silva VAN, Pereira RMS, Guidoreni CG, Gomes MP. Diagnóstico e tratamento de sífilis durante a gestação: desafio para enfermeiras? Saúde Pesq. 2018;11(2):249-55. DOI: http://dx.doi.org/10.17765/1983-1870.2018v11n2p249-255

20. Rodrigues ARM, Silva MAM, Cavalcante AES, Moreira ACA, Mourão Netto JJ, Goyanna NF. Atuação de enfermeiros no acompanhamento da sífilis na Atenção Primária. Rev Enferm UFPE On Line. 2016;10(4):1247-55. DOI: 10.5205/1981-8963-V10i4a11111p1247-1255-2016

21. Kuznik A, Habib AG, Manabe YC, Lamorde M. Estimating the public health burden associated with adverse pregnancy outcomes resulting from syphilis infection across 43 countries in sub-Saharan Africa. Sex Transm Dis. 2015;42(7):369-75. DOI: http://dx.doi.org/10.1097/ OLQ.0000000000000291

22. Conselho Federal de Enfermagem. Nota Técnica Cofen/CTLN n. 03/2017. Dispõe sobre esclarecimentos aos profissionais de enfermagem, sobre a importância da administração da Penicilina Bezantina nas Unidades Básicas de Saúde do Sistema Único de Saúde [Internet]. Brasília; 2017 [citado 2019 jan. 30]. Disponível em: http://www.cofen.gov.br/wp-content/uploads/2017/06/NOTAT\%C3\%89CNICA-COFEN-CTLN-N\%C2\%B0-03-2017.pdf

23. Rocha KB, Santos RRG, Conz J, Silveira ACT. Network transversality: matrix support in the decentralization of counseling and rapid testing for HIV, syphilis, and hepatites. Saúde Debate. 2016;40(109):22-33. DOI: http://dx.doi.org/10.1590/0103-1104201610902

24. Previati SM, Vieira DM, Barbieri M. A importância do aconselhamento no exame rápido de HIV em gestantes durante o pré-natal. J Health Biol Sci. 2019;7(1):75-81. http://dx.doi.org/10.12662/2317-3076jhbs.v7i1.2104.p75-81.2019

25. Araújo CLF, Aguiar PS, Santos GKA, Oliveira MGP, Câmara LS. Anti-HIV testing in gynecology services in the city of Rio de Janeiro. Esc Anna Nery. 2014;18(1):82-9. DOI: https://doi.org/10.5935/1414-8145.20140012

26. Taquette SR, Rodrigues AO, Bortolotti LR. Perception of pre- and post-HIV test counseling among patients diagnosed with aids in adolescence HIV test counseling for adolescents. Ciênc Saúde Coletiva. 2017;22(1):23-30. DOI: http://dx.doi.org/10.1590/1413-81232017221.23532015

27. Villas Bôas LMFM, Araújo MBS, Timóteo RPS. A prática gerencial do enfermeiro no PSF na perspectiva da sua ação pedagógica educativa: uma breve reflexão. Ciênc Saúde Coletiva. 2008;13(4):1355-60. DOI: http://dx.doi.org/10.1590/S1413-81232008000400033 


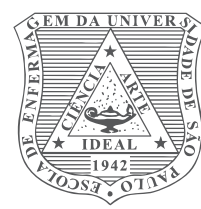

Erratum: Team adherence to rapid prenatal testing and administration of benzathine penicillin in primary healthcare

In the article "Team adherence to rapid prenatal testing and administration of benzathine penicillin in primary healthcare", DOI: https://doi.org/10.1590/S1980-220X2019006203645, published by the journal "Revista da Escola de Enfermagem da USP", Volume 54 of 2020, elocation e03645, on page 4, Figure 2, item "HIV, Syphilis and Hep. C":

Where was written:

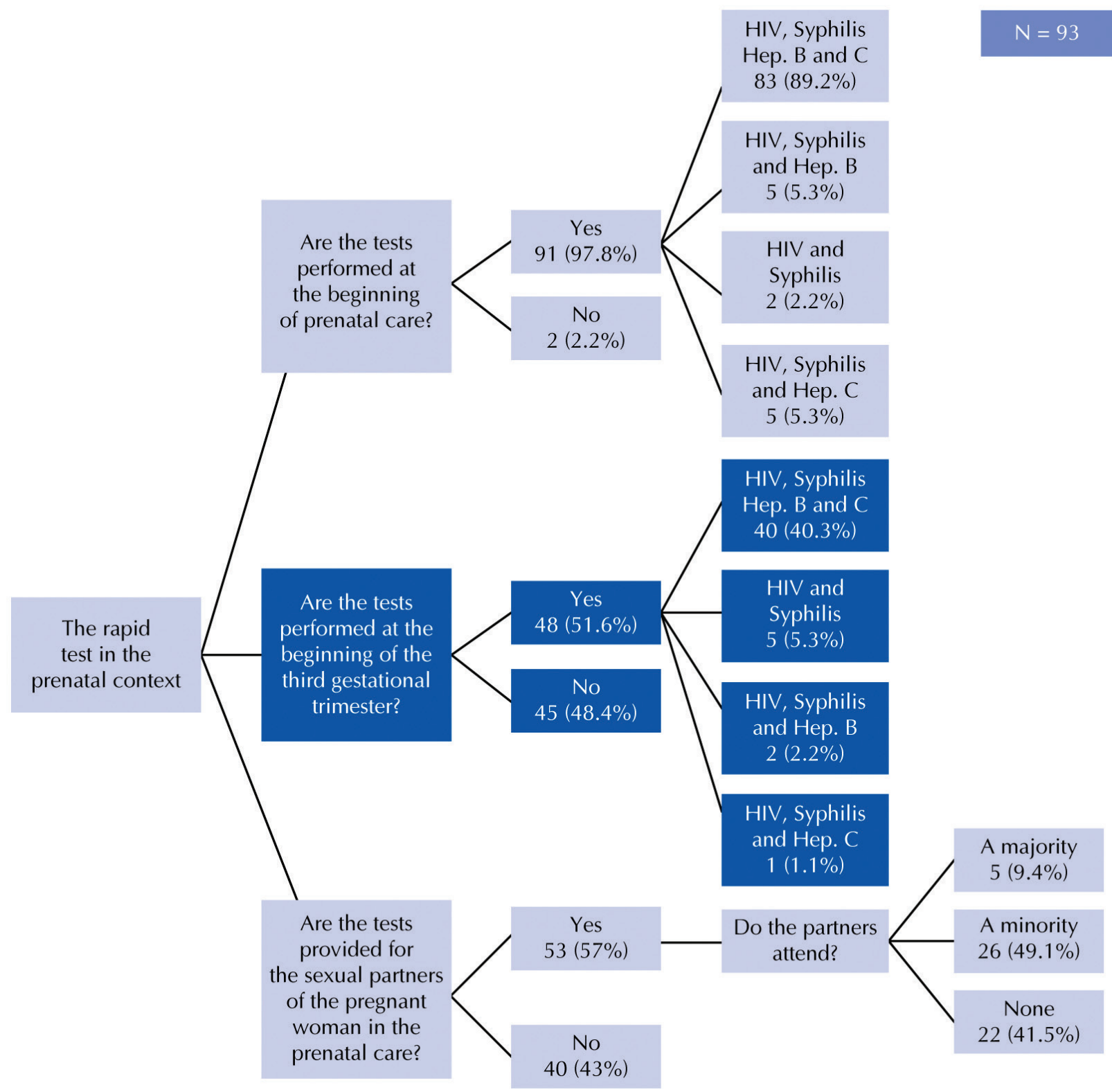


Now read:

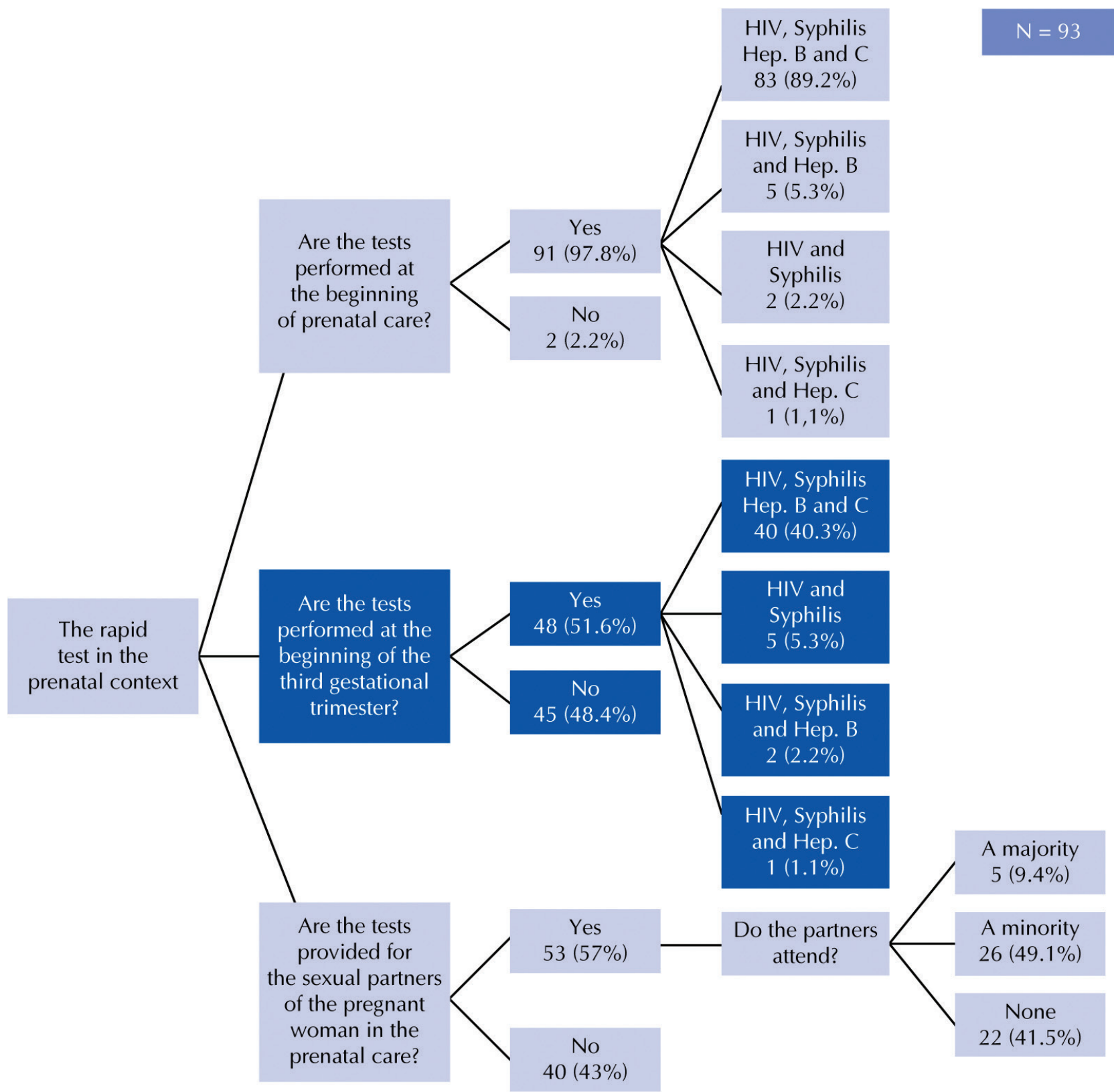

